more opportunity should be afforded to the physicist engaged in wireless work to become a member of the Institution. This recommendation was approved by the Council and has continuously been acted upon by the committees responsible for electing new members; it is particularly opportune to direct attention to it at the present time, when a large number of men engaged on wireless work would probably refer to themselves as radio physicists rather than wireless or radio engineers.

Among other recommendations made in the report referred to above was one to the effect that all papers and discussions of a wireless nature should be published in a separate Proceedings of the Wireless Section as well as in the Journal of the Institution. For this every member of the Wireless Section must be very grateful. Fifteen volumes of these Proceedings were published during the period 1926-40, and these contain a most valuable record of the progress of wireless engineering research and development in a very compact form and free from the large mass of other papers published by the Institution and in which the wireless engineer has little more than general or passing interest. With the revision of the form of the Journal, which was necessitated by paper shortage considerations in 1940, the existence of these Proceedings formed a most valuable precedent for ensuring that papers on wireless were still published separately as Part III of the present-day Journal. It is very clear that as regards the provision of scope and opportunities for publication, no separate society or association could serve its members better than the Institution has done during the past sixteen years and still continues to do in a very satisfactory manner.

Dr. Smith-Rose next referred to the work of the Radio Research Board, with which he has been associated since its establishment in 1920 under the Department of Scientific and Industrial Research. Although concerned mainly with investigations of a fundamental nature, many of the aspects of the Board's programme are determined from time to time by the needs of the defence departments and of the Post Office and B.B.C., each of which has been represented on the Board itself and on all its technical committees. The Board makes its recommendations to the Department of Scientific and Industrial Research, which is responsible for providing the means and facilities for the conduct of the work; in recent years practically the whole programme has been entrusted to the Radio Department of the National Physical Laboratory for execution. Apart from the official reports of the Radio Research Board issued from time to time, the majority of the investigation work has been described in papers and reports published by the Institution of Electrical Engineers and other scientific societies. As an indication of the widespread nature of this publication it may be pointed out that of the 246 papers that have been published in the Proceedings of the Wireless Section during the past sixteen years, no less than eighty of them have been presented by staff working under the auspices of the Radio Research Board.

Little can be said about the recent investigations in hand, since for the past three years the work has been devoted entirely to the furtherance of the prosecution of the radio technical war in the manner in which is considered to be most useful. A conspicuous feature of this recent work has been to realize the fruition in direct Service application of all the long-term investigations sponsored for many years past by the Radio Research Board. The present value of pre-war fundamental work on direction-finding and ultra-short-wave propagation, suitably oriented to meet present conditions, is immediately obvious; but by now most of the apparently more academic subjects under investigation have suddenly been elevated to Service applications of the highest priority. Even some of the research items which had been abandoned in the past as having little or no interest have had to be revived to meet pressing demands, and it is often the fact of having already explored the technique and satisfactorily established the fundamental principles of a particular field that provides the advantage over the enemy in the technical conduct of the war. In some spheres the demand is for basic principles of design of apparatus and equipment which was developed originally as a research tool, and now has to be adapted to more practical application; in other spheres it is accurate measuring equipment and technique that is sought; while in yet other directions the request is for information that will define the present possibilities of radio communication, and more especially what these are likely to be in the immediate future.

\section{AUSTRALIAN ASSOCIATION OF SCIENTIFIC WORKERS}

$T$ HE Australian Association of Scientific Workers called two conferences of scientific workersone in Sydney on February 21-22, and one in Melbourne on March 7-8-to consider the use being made of scientific men in Australia in furthering the war effort.

The Melbourne Conference was attended by about one hundred and thirty members. Industrial undertakings and Government enterprises were almost equally represented; the younger members were in great majority. There was apparent a certain restraint in expressing views, possibly due in part, at least, to the more senior members not giving a lead. There was no doubt at all of the sincere wish to give all services required, but there was apparent deep misgivings whether the Government understood and appreciated what could be done-and can be doneby scientifically trained people given problems to solve; indeed, the opinion was expressed that the scientific men themselves had a duty (1) in seeing for themselves what problems needing immediate solution already existed, (2) in anticipating problems that would inevitably arise, and (3) in suggesting methods of solution and carrying them out. But the doubt was raised whether the Government has confidence in scientific men, or whether it is just a lack of understanding on the part of the scientific men of political methods.

Among the more important problems discussed were : lack of understanding of industrial fatigue ; absence of suitable bodies to study this problem in factories; the inability to make use of experience gained elsewhere; lack of foresight in planning for supplies, especially in agriculture, and in pooling information of plant practices; the wastage of scientifically trained man-power in the Fighting Forces.

It was stated that little or no use is being made of the professional registers; and that the examina- 
tion of inventions is neglected in many cases. Waste and by-products useful in certain industries are being neglected, while other industries could put many of them to good use, and have, in fact, been wanting some of these products. There appeared to be lack of co-ordination of efforts in industries engaged on similar work.

In short, problems which have been engaging the attention of scientific men in Great Britain, and many of which have been solved, are being experienced in Australia also.

The results of the debates were crystallized in ten resolutions which are now being communicated to the appropriate authorities. It is hoped that action will be taken by the Government. The Australian Association of Scientific Workers proposes to watch developments, and will make use of its special knowledge to see that better use is made of Australian scientific resources and man-power.

\section{PACIFIC RELATIONS IN THE POST- WAR WORLD}

$\mathrm{T}$ HE second of the series of reports on the United States in a new world, based on the findings of a committee of the editors of Time, Life and Fortune set up to study post-war problems, is of particular interest as indicating the trend of advanced American thought on Pacific relations. The proposals are based on a belief in the greatness of Asia, and on the view that progress towards free and more abundant life in times of peace must be mainly concerned with a practical solution of the problems of productivity, literacy and common law and order, and that the East needs the social inventions of the West just as much as its technology. It is assumed that in the largest degree the peoples of Asia must work out their own solution, and the preference for strong and effective international authority is clearly indicated; although it is recognized that the United States may, in certain circumstances, have to be the principal trustee of the United Nations, while others are growing into modernity or recovering from the consequences of the War. The report proposes an organization to be called the Pacific Council, which would be the final judicial authority of the United Nations on Pacific affairs, although for the co-operative international administration required in specific jobs, the organization of special co-operative bodies is suggested, representing only those members of the United Nations which have a legitimate interest in the specific tasks.

The first of these tasks proposed is that of creating a nation in South-Eastern Asia. Coupled with an independent Philippines, it is suggested that new States should be created out of the other ex-colonies of Indonesia. The first and largest of these States would consist of Thailand, British Malaya, all the British and Dutch Islands in Indonesia and Portuguese Timor, with the political status of an international republic, in which it is suggested the ability and responsibility of the Dutch Colonial administrators will find ample scope. For the creation of this State the ultimate reasons are military and economic. In regard to Burma, it is suggested that Great Britain should transfer its rights to an international commission, on which Great Britain, India, China and the
United States would be strongly represented, which would conclude an agreement with China concerning its transit rights on the Burmese roads, railways and rivers, and in the port of Rangoon. The first task of this commission would be that of physical reconstruction. It is suggested that France might be induced to agree to a similar course for Indo-China, after the preliminary restoration of French sovereignty.

While long-term control and disarmament of Japan is not considered feasible, it is suggested that if an American-Chinese-British-Dutch Group took over the Japanese aviation monopoly and its installations under a contract to run for 25-50 years, its operation would preclude any effective secret Japanese rearmament. Transfer of Japanese investments in Manchuria and China to China is suggested, and control of Japan's merchant marine should be vested in a Combined Shipping Board. The best hope for a change of heart in Japan is regarded as lying in the total discrediting of its military leaders and their followers, and in a resulting resolve of the Japanese people themselves to oust them.

With regard to China, the more serious specific problems to be solved are those of agriculture, industrialization, the restoration of an economic industrial balance, transport and education. All these principal problems are interrelated and formidable, but the building of a strong and free China is a Chinese task. The interdependence of China and other nations including the United States is recognized, however, and industrialization can only come naturally as part of a general international expansion if China is certain that such international economic expansion will occur, as expansion depends fundamentally on American participation. The approach to post-war economic relations can only be freed from mutual suspicion by a better understanding of the facts. The Chinese problem is to secure the essential financial and technical assistance from abroad, without paying for it through impaired sovereignty or the loss of control over national resources. The report strongly supports the participation in a free market area open to every nation, and Chinese exports should not be debarred from American markets by high duties. Economic relations with China require the admission of Chinese goods in payment of Chinese obligations, and the cheap imports would benefit the general United States public.

The danger to American industry and standards of living is discounted, and it is considered that one article of the mutual aid agreement should keep Asiatic, and especially Chinese, protectionism within bounds. These are the general principles for future and long-range application, and immediate measures should be taken with these objects in view. Reconstruction grants on a minor scale should greatly assist co-operation in the field of higher education, and the services of highly skilled scientific men and technicians are likely to be in very high demand in post-war China. The report frankly faces the changes in the American immigration law, which, like changes in the tariff, will be required. Leading problems of Korea, India, the South Pacific and New Zealand are briefly reviewed, and while the idea of a Pacific counterpart of the Atlantic Charter is discounted, the importance of establishing cordial confidence as a basis of unity and high morale in the United Nations is emphasized. 